\title{
MODEL KOMUNIKASI UNTUK MEMBANGUN KESIAPAN PERUBAHAN
}

\author{
Akhmad Edhy Aruman ${ }^{1}$, Sumardjo ${ }^{2}$, Nurmala Katrina Panjaitan ${ }^{2}$, Dwi Sadono ${ }^{2}$ \\ ${ }^{1}$ Ilmu Komunikasi STIKOM LSPR Jakarta \\ ${ }^{2}$ Departemen Sains Komunikasi dan Pengembangan Masyarakat, Fakultas Ekologi \\ Manusia, Institut Pertanian Bogor
}

\begin{abstract}
This study aims to formulate a communication model to build the readiness of changes in traditional market traders. This research is related to traditional market revitalization plan to face competition especially from modern retailer. The method used is survey which result is analyzed by using causality approach with LISREL tool and reinforced with result from depth interview. The result is in the picture that in the face of revitalization, traders are in a situation of uncertainty. On the other hand, overall elements ranging from trader characteristics, message sources, messages, and participatory communications have a positive impact on merchant readiness associated with revitalization with high-capacity merchant corporation conditions. However, to build the readiness of traders, the main thing to do is to build the entrepreneurial capacity of traders. The lack of success in building entrepreneurial capacity has a negative impact on the readiness of traders. Appropriate communication models involving market managers as a credible source of messages, message content on the benefits and risks of effective revitalization develop the trader's motivation to change, and the media that permits immediate responses from communication actors.
\end{abstract}

Keywords: participatory communication, uncertainty, message of change, kekosmopolitan, readiness of change

\begin{abstract}
ABSTRAK
Penelitian ini bertujuan untuk merumuskan model komunikasi untuk membangun kesiapan perubahan pedagang pasar tradisional. Penelitian ini dilakukan terkait dengan rencana revitalisasi pasar tradisional untuk menghadapi persaingan terutama dari peritel modern. Metode yang digunakan adalah survey yang hasilnya dianalisis dengan menggunakan pendekatan kausalitas dengan alat bantu LISREL dan diperkuat dengan hasil dari wawancara mendalam. Hasilnya diperoleh gambaran bahwa dalam menghadapi revitalisasi, pedagang berada dalam situasi ketidakpastian. Di sisi lain, secara keseluruhan unsur mulai dari karakteristik pedagang, sumber pesan, pesan, dan komunikasi partisipatif memberikan dampak positif terhadap kesiapan pedagang terkait dengan revitalisasi dengan kondisi kapasitas keriwausahaan pedagang tinggi. Namun demikian, untuk membangun kesiapan pedagang, hal utama yang perlu dilakukan adalah membangun kapasitas kewirausahaan pedagang. Kurang berhasilnya pembangunan kapasitas kewirausahaan menghasilkan dampak negatif terhadap kesiapan pedagang. Model komunikasi yang dinilai tepat melibatkan pengelola pasar sebagai sumber pesan yang kredibel, muatan pesan tentang manfaat dan risiko revitalisasi efektif mengembangkan motivasi pedagang untuk berubah, dan media yang memungkinkan terjadi tanggapan langsung dari pelaku komunikasi.
\end{abstract}

Kata kunci: komunikasi partisipatif, ketidakpastian, pesan perubahan, kekosmopolitan, kesiapan perubahan 


\section{PENDAHULUAN}

Dalam beberapa tahun terakhir, pasar tradisional yang memiliki peran strategis tersaingi oleh kehadiran supermarket yang semakin menjamur di kotakota besar dan kota-kota kabupaten. Dinamika perubahan ini tidak direspon secara cepat oleh pengelola dan pedagang sehingga pasar tradisional kalah dibandingkan supermarket.

Kondisi pasar tradisional kumuh, kotor, becek, tidak terawat, tingkat kualitas hunian sangat rendah, tidak aman, dan sumber kemacetan lalu lintas. Pedagang pasar tradisional kurang menyadari pentingnya peningkatan fasilitas layanan (kebersihan, kenyamanan dan keamanan pasar) sebagai salah satu upaya meningkatkan daya tarik pasar (Rahayuningrum dan Widayanti 2008). Akibatnya, kondisi usaha dan kinerja pedagang pasar tradisional turun setelah beroperasinya hypermarket. Pemilikan kekayaan (aset) stagnan dan bahkan menurun.

Pasar tradisional diartikan sebagai pasar yang dibangun oleh pemerintah, swasta, koperasi atau swadaya masyarakat dengan tempat usaha berupa toko, kios, los dan tenda yang dimiliki/dikelola oleh pedagang kecil dan menengah atau koperasi dengan usaha skala kecil dan modal kecil dengan proses jual beli melalui tawar menawar.

Pada tahun 2007, Pemerintah Indonesia mengeluarkan kebijakan untuk meningkatkan kembali (revitalisasi) peran pasar tradisional. Ini ditunjukkan dengan adanya Peraturan Presiden Nomor 112 Tahun 2007 tentang Pengaturan dan Pengembangan Pasar Tradisional, Pusat Perbelanjaan, dan Toko Modern, yang mencoba melindungi pasar tradisional dari penetrasi tak terkendali dari pasar modern (Santosa dan Indroyono 2011).

Revitalisasi dilaksanakan dengan merenovasi pasar-pasar tradisional. Tujuannya agar pasar tradisional yang semula kumuh, tidak aman, tidak nyaman dan sebagainya berubah menjadi seperti pasar modern yang nyaman, bersih, rapi, dan barang-barang yang dijual sesuai dengan kebutuhan masyarakat dengan kualitas yang sama dengan yang dijual di supermarket untuk tingkatan harga yang sama, tetapi masih dengan sistem jual beli tradisional, dan memiliki fungsi dan peran pasar sebagai wadah komunikasi dan informasi. Pada kenyataannya program revitalisasi pasar tradisional tidak sepenuhnya menunjukkan keberhasilan. Sebagian besar pasar yang terbangun dari program revitalisasi belum sepenuhnya berfungsi optimal. Banyak pedagang yang melakukan protes revitalisasi pasar (Kompas.com, 22/5/2014).

Fenomena ini memunculkan pertanyaan seputar proses komunikasi menjelang, selama dan paska revitalisasi. Berdasarkan uraian latar belakang tersebut, rumusan masalah yang diajukan dalam rencana penelitian ini adalah (1) bagaimana proses komunikasi antara pengelola pasar dan para pedagang selama proses perubahan budaya di pasar tradisional? (2) faktor-faktor komunikasi apa saja yang berpengaruh terhadap kesiapan pedagang pasar tradisional menuju perubahan budaya? Dan (3) bagaimana model komunikasi organisasi antara 
pengelola dan pedagang pasar untuk memfasilitasi proses perubahan budaya revitalisasi pasar tradisional.

Tujuan dari penelitian ini adalah selain mendeskripsikan proses komunikasi yang berlangsung antara pengelola pasar dan pedagang pasar, membuktikan apakah karakteristik pedagang, sumber pesan, terpaan pesan, komunikasi interaktif dan dukungan lingkungan mempengaruhi kesiapan pedagang untuk melakukan perubahan, juga menemukan model komunikasi untuk membangun kesiapan menghadapi perubahan revitalisasi pasar.

\section{TINJAUAN PUSTAKA}

\section{Komunikasi Membangun Kesiapan Berubah}

Proses perubahan biasanya ditandai dengan konflik yang dapat bersifat positif dan negatif. Konflik menjadi negatif jika tidak ada komunikasi yang baik antara pihak manajemen dengan anggota organisasi, dan sebaliknya apabila terjadi komunikasi yang baik. Komunikasi yang baik antara pemangku kepentingan merupakan aspek penting dalam mendukung perubahan di dalam organisasi.

Dengan komunikasi yang baik maka pihak-pihak yang terlibat dalam perubahan dapat menerima perubahan dan memahami bahwa perubahan memang perlu dilakukan untuk kebaikan organisasi. Madsen et al. (2005) menyarankan agar organisasi membangun kesiapan pemangku kepentingannya untuk menghadapi perubahan. Dengan demikian, langkah pertama dalam proses pelaksanaan inisiatif perubahan adalah menciptakan kesiapan untuk perubahan (Self dan Schraeder 2008). Kesiapan untuk berubah didefinisikan sebagai sikap komprehensif yang secara stimultan dipengaruhi oleh isi pesan, proses, konteks, dan individu yang terlibat dalam suatu perubahan, merefleksikan sejauh mana kecenderungan individu untuk menyetujui, menerima, dan mengadopsi rencana spesifik yang bertujuan utuk mengubah keadaan saat ini (Holt et al. 2007).

Komunikasi yang baik selama perubahan dapat menumbuhkan pemahaman, menyelaraskan antara tujuan organisasi dan individu-individu dalam organisasi tersebut, dan mempermudah interaksi di antara yang terlibat dalam perubahan, menjadi panduan dan memotivasi mereka. Menurut Merrell (2012), individuindividu di dalam organisasi yang memiliki manajemen perubahan baik, pada umumnya saling berkomunikasi tentang perubahan dengan baik pula.

Pentingnya melibatkan masyarakat dalam pengambilan keputusan kebijakan telah lama diakui banyak ahli, sebab ada keyakinan bahwa partisipasi masyarakat dalam perdebatan publik dapat meningkatkan kualitas pengambilan kebijakan (Bichard, 1999). Meskipun keterlibatan masyarakat diperlukan hanya sebatas konsultasi atau "tokenisme" (Arnstein 1969), praktik tersebut memungkinkan anggota masyarakat menyuarakan kebutuhan mereka dan didengar oleh lembaga. Menurut Mubyarto (1985), partisipasi merupakan kesadaran untuk membantu berhasilnya setiap program sesuai dengan kemampuan setiap orang tanpa berarti mengorbankan kepentingan diri sendiri. 
Beberapa peneliti menekankan pentingnya penyusunan perencanaan kolaboratif dalam proses pembangunan. Perencanaan kolaboratif ini memanfaatkan komunikasi sebagai dasar dalam proses berikutnya (rasionalitas komunikatif). Mengacu pada Schramm, Kincaid, Rogers dan Kincaid dan Swanson, Sumardjo (1999) menyatakan bahwa model komunikasi interaktif ini sejalan dan memperhatikan prinsip-prinsip yang berlaku dalam model komunikasi tipe relasional maupun tipe-tipe konvergen. Model komunikasi konvergen maupun interaktif, menurut Sumardjo (1999), bersifat dua arah, yakni partisipatif baik vertikal maupun horisontal. Artinya, keputusan di tingkat perencanaan program pembangunan sangat memperhatikan kebutuhan dan kepentingan di tingkat bawah.

Komunikasi partisipatif adalah suatu proses komunikasi dua arah atau dialogis, sehingga menghasilkan suatu pemahaman yang sama terhadap pesan yang disampaikan (Rahim 2004). Dialog adalah komunikasi transaksional dimana pengirim (sender) dan penerima (receiver) pesan saling berinteraksi dalam suatu periode waktu tertentu hingga sampai pada makna-makna yang saling berbagi. Dalam dialog tersebut, menurut Innes dan Booher (2010), setiap aktor yang duduk bersama saling menghargai, berempati, terjadi hubungan timbal balik dan saling menguntungkan.

Oleh karena itu, komunikasi perubahan yang bersifat dialogis penting dilakukan sebagai alternatif mengatasi penolakan atau perlawanan terhadap perubahan. Komunikasi juga membuka peluang bagi semua yang memiliki kepentingan untuk berpartisipasi dalam perubahan sehingga komunikasi dianggap sebagai salah satu cara untuk membantu mengurangi sikap-sikap negatif terhadap transformasi hingga ke masalah pengaturan kerja.

Proses komunikasi partisipatif ini melibatkan sumber pesan yang kredibel (Berlo 1969; Pornpitakpan 2004), pesan persuasif (Crowley dan Hoyer's 1994), saluran pesan (Fulk et al. 1990) dan penerima pesan. Berdasarkan pendapatpendapat tersebut, terwujudnya perencanaan kolaboratif membutuhkan komunikasi patisipatif yang didasarkan pada adanya dialog, umpan balik, kebersamaan, rasa saling percaya antara pengelola perubahan dan masyarakat, rasa keadilan dan kualitas saluran komunikasi yang digunakan.

Berdasarkan gagasan-gagasan di atas maka disusun kerangka pemikiran sebagai berikut: 


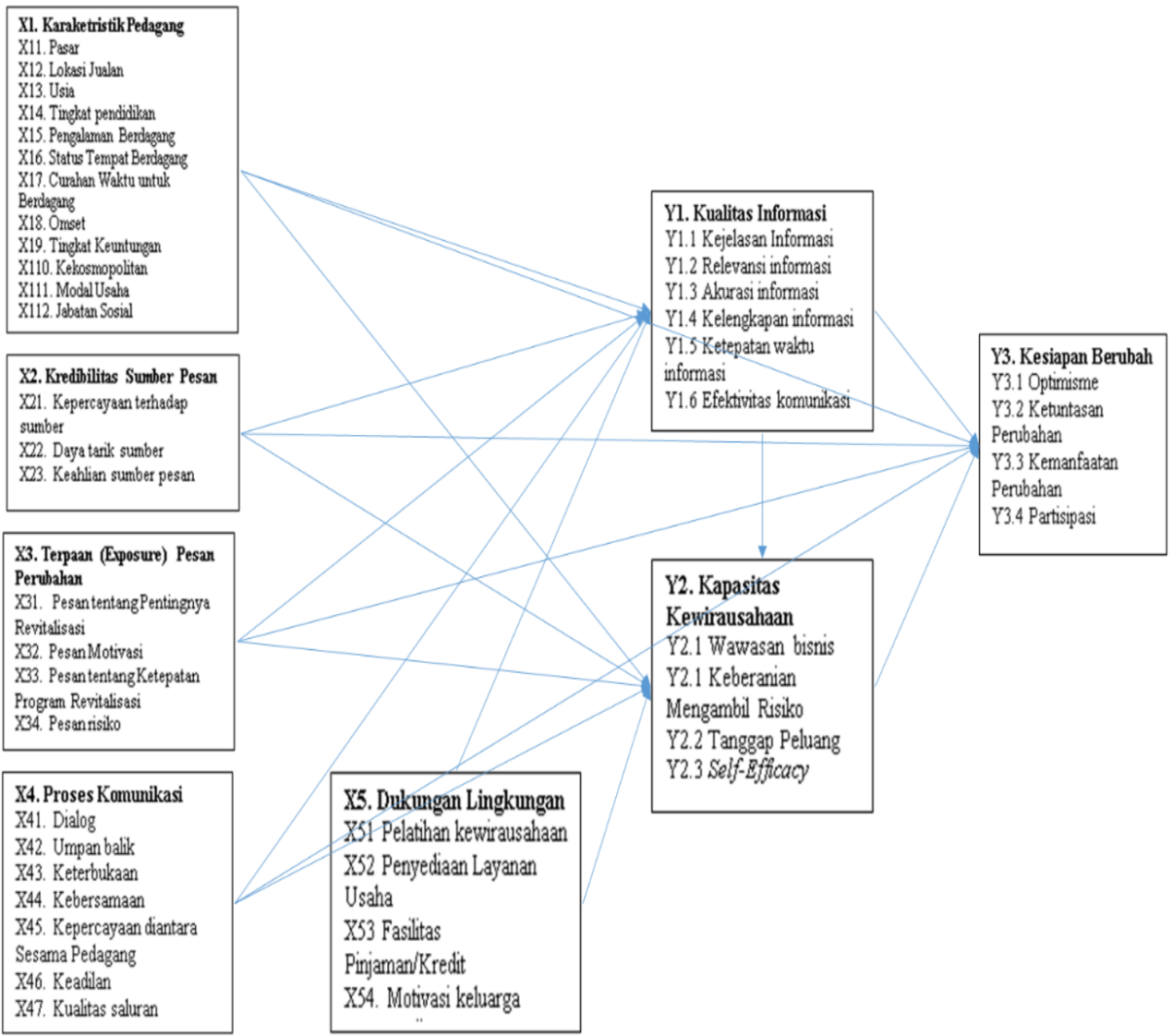

Gambar 1. Kerangka Pemikiran Model Komunikasi untuk Membangun Kesiapan Berubah

\section{METODE PENELITIAN}

Untuk menemukan jawaban atas pertanyan penelitian, penelitian dilakukan dengan menggunakan pendekatan survey dan datanya dianalis secara deskriptif dan inferensial. Pemilihan lokasi penelitian dilakukan secara sengaja (purposive) dengan mempertimbangkan bahwa objek dipilih karena menghadapi persoalan revitalisasi dan pengelola pasar. Ada empat pasar yang diteliti dan semuanya adalah milik pemerintah kota. Waktu pelaksanaan penelitian Februari - Juli 2016.

Populasi dalam penelitian ini meliputi pedagang di empat pasar tadi. Populasi pedagang di empat pasar tersebut berada pada kisaran 1500 pedagang. Menurut Neuman (2006), melalui 30 persen dari populasi dengan jumlah di bawah 1000 adalah memadai untuk tingkat akurasi. Berdasarkan hal tersebut peneliti menentukan ukuran sample sebesar 559 responden yang dipilih secara acak.

Analisis data dalam penelitian ini menggunakan analisis deskriptif untuk memberikan gambaran tentang komunukasi yang dilakukan, dan menguji hubungan antar peubah dan analisis sebab akibat melalui regresi berganda dengan menggunakan model Stuctural Equation Model (SEM) yang dioperasikan melalui Lisrel. Peubah dalam penelitian ini terdiri atas (1) karakteristik pedagang, (2) kredibilitas sumber pesan, (3) terpaan pesan perubahan, (4) komunikasi 
partisipatif, (5) dukungan lingkungan, (6) kualitas komunikasi, (6) kapasitas kewirausahaan, dan (7) kesiapan untuk berubah.

Berdasarkan pemasalahan penelitian, tujuan penelitian dan kerangka berfikir yang telah dijelaskan sebelumnya, dirumuskan hipotesis penelitian berikut:

(1) Karakteristik pedagang, kredibilitas sumber pesan, terpaan pesan perubahan, komunikasi partisipasif, dan dukungan lingkungan mempengaruhi kualitas komunikasi, kapasitas kewirausahaan, dan kesiapan untuk berubah.

(2) Tingkat kesiapan berubah dipengaruhi secara langsung dan tidak langsung oleh kapasitas kewirausahaan, kualitas komunikasi, dukungan lingkungan, komunikasi partisipatif, terpaan pesan perubahan, kredibilitas sumber pesan dan karakteristik pedagang.

\section{HASIL DAN PEMBAHASAN}

Hasil uji kesesuaian model menunjukkan bahwa hybrid model yang diperoleh (Gambar 2) adalah fit. Indikator Goodness of Fit juga bisa dilihat dari rasio perbandingan antara nilai Chi-Square dan degree of freedom $\chi^{2} / \mathrm{df}$. Rasio $\chi^{2} / \mathrm{df}$ dalam model tersebut adalah $1840 / 467=3.9$. Menurut Carmines dan Mclver (1981) besar rasio yang baik adalah sebesar 2. Dengan demikian, model yang dihasilkan melalui penelitian ini dapat digeneralisasikan.

Gambar 2 memperlihatkan bahwa karakteristik pedagang, kredibilitas sumber pesan, terpaan pesan perubahan, komunikasi partisipasif, dan dukungan lingkungan mempengaruhi kualitas komunikasi, kapasitas kewirausahaan, dan kesiapan untuk berubah. Dengan demikian untuk membangun kesiapan pedagang dalam menghadapi perubahan, tindakan komunikasi membutuhkan komunikasi partisipatif dengan penyampai pesan yang kredibel, pesan perubahan, dukungan lingkungan, komunikasi yang berkualitas, dan kapasitas kewirausahaan. Semakin tinggi tingkat pendidikan, omset, tingkat keuntungan dan modal untuk berdagang membutuhkan kualitas komunikasi yang semakin tinggi atau informasi yang relevan, jelas, akurat dan lengkap. Variabel dengan pengaruh tertinggi adalah relevansi informasi.

Faktor lain yang mempengaruhi kualitas komunikasi adalah kredibilitas pengelola pasar sebagai sumber pesan. Gambar 2 menunjukkan bahwa kredibilitas pengelola pasar berpengaruh langsung dan positif terhadap pembentukan kualitas komunikasi. Hal ini menunjukkan bahwa dalam komunikasi untuk membangun semakin tingi kredibilitas pedagang pasar, semakin tinggi kualitas komunikasi. Kredibilitas pengelola pasar memberikan kontribusi baik langsung maupun tidak langsung terhadap kapasitas kewirausahaan. Secara langsung, pengaruh kredibilitas pengelola negatif dan secara tidak langsung positif terhadap kapasitas kewirausahaan. Namun secara keseluruhan, kredibilitas pengelola pesan berpengaruh positif terhadap kapasitas kewirausahaan. 


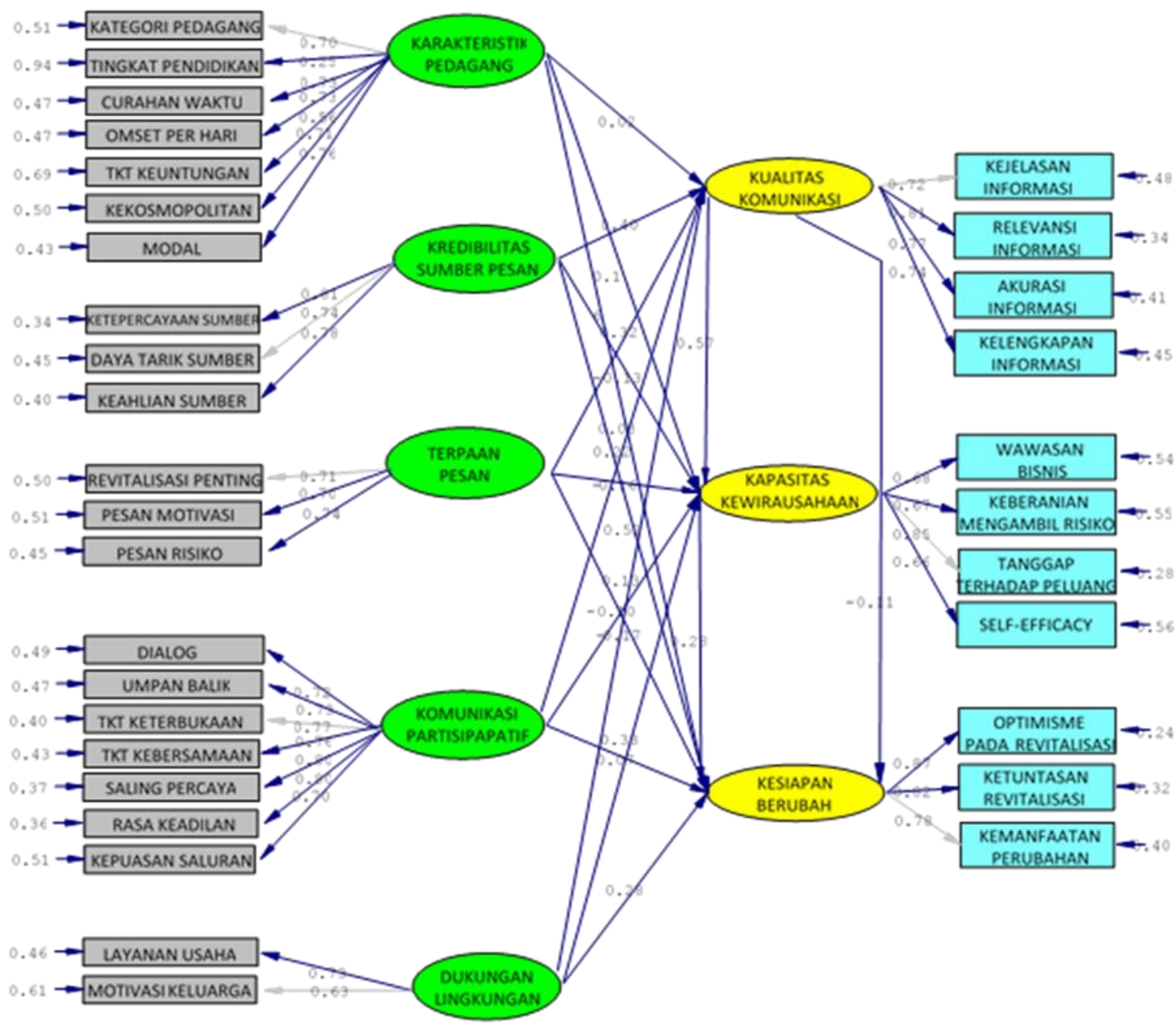

Chi-Square $=1840.10, d f=467, \mathrm{p}-\mathrm{value}=0.00000, \mathrm{RMSEA}=0.073$

Gambar 2 . Dekomposisi Pengaruh Antar Peubah Komunikasi dan Kesiapan untuk Berubah

Hal ini menunjukkan bahwa upaya meningkatkan kapasitas kewirausahaan pedagang pasar melalui peningkatan kredibilitas (kepercayaan pedagang terhadap pengelola pasar, keahlian pengelola pasar, dan daya tarik pengelola pasar) meningkatkan kapasitas kewirausahaan pedagang pasar bila dalam berkomunikasi pengelola pasar juga memberikan informasi yang relevan, jelas, akurat dan lengkap. Tanpa komunikasi yang berkualitas dan meningkatkan kredibilitas, bisa menurunkan kapasitas kewirausahaan pedagang pasar.

Hasil penelitian menunjukkan bahwa pesan-pesan tentang risiko kurang dikemukakan oleh pengelola pasar (1.78 dari skala 3 ). Pesan risiko ini misalnya kemungkinan yang terjadi bila revitalisasi gagal dilaksanakan, termasuk dampak negatif yang terjadi karena revitalisasi pasar. Menurut Miller dan Monge (1985), selama proses perubahan, orang cenderung lebih menyukai pesan atau informasi, termasuk informasi yang negatif.

"Yang disampaikan hanya dampak positifnya. Dampak negatif setelah pasar direvitalisasi tidak dijelaskan," (Pedagang Narasumber I)

Penelitian yang dilakukan Crowley dan Hoyer's (1994) menunjukkan bahwa penggunaan pesan dua-sisi menghasilkan tanggapan yang diharapkan oleh 
pembuat atau penyampai pesan. Menurut mereka, pesan dua sisi biasanya menunjukkan kebaruan, menarik, kredibel dan mendorong audience untuk memperhatikan dan memberikan motivasi. Selain itu, membuat pesan menjadi lebih kredibel termasuk dalam situasi ketika pesan negatif berdatangan.

Dari sini diperoleh gambaran bahwa apabila pengelola pasar menyampaikan informasi negatif tentang dampak revitalisasi, pedagang mempersepsikan pengelola pasar sebagai orang yang kredibel dan menguasai masalah revitalisasi. Ini karena pedagang menganggap bila pengelola menyampaikan dampak negatif setelah revitalisasi, pedagang menganggap pengelola menguasai masalah. Ini sekaligus menunjukkan keahlian penyampai pesan yang merupakan faktor penting dalam meningkatkan kredibilitas sumber pesan.

Pasar merupakan fasilitas publik yang dalam penyediaannya membutuhkan adanya keputusan publik. Keputusan publik sangat terkait dengan proses demokrasi, maka pengembangan komunikasi pembangunan dalam penyediaan prasarana pasar hendaknya juga memperhatikan bagaimana tipologi berdemokrasi yang ada di kawasan pasar dibangun tersebut.

Hasil penelitian menunjukkan bahwa komunikasi partisipatif memberikan dampak positif terhadap kualitas komunikasi. Dengan kata lain, dengan komunikasi pertisipatif, pengelola mampu memberikan informasi yang jelas, relevan, akurat dan lengkap. Komunikasi partisipatif juga memberikan dampak yang positif terhadap kesiapan pedagang berkaitan dengan revitalisasi. Akan tetapi, komunikasi partisipatif memberikan dampak negatif pada kapasitas kewirausahaan sehingga menurunkan dampak positifnya terhadap kesiapan pedagang dalam kaitannya dengan revitalisasi.

Dari model di atas dapat dilihat bahwa pengembangan kapasitas kewirausahaan merupakan faktor utama pembentuk kesiapan pedagang untuk berubah. Dukungan lingkungan penting, namun dukungan tersebut baru memberikan kontribusi positif bagi pembangunan kesiapan pedagang untuk berubah bila mampu meningkatkan kapasitas kewirausahaan. Ini karena dukungan lingkungan justru memberikan pengaruh yang arahnya negatif kepada kesiapan pedagang untuk berubah.

\section{Model Komunikasi}

Model komunikasi merupakan penyederhaan dari sesuatu yang abstrak ke yang mendekati realitas, atau mendekati yang asli. Dengan model seseorang bisa melakukan seleksi, menemukan elemen-elemen kunci, dan cara mengindikasikan interaksi dan relasi antara beberapa elemen-elemen (McQuail dan Windhal 1989). Dapat dimaknai bahwa suatu model terdiri dari beberapa elemen yang saling mempengaruhi dan mengontrol satu sama lain melalui mekanisme timbal balik sehingga bisa menjelaskan sesuatu fenomena (Liliweri 2011).

Komunikasi merupakan interaksi antara pengirim pesan dan penerima pesan. Gagasan ini mengasumsikan bahwa dalam komunikasi, baik penyampai pesan maupun penerima pesan berada dalam kedudukan yang setara. Kesetaraan membuat proses yang terjadi menghasilkan fenomena sebab akibat atau aksi-reaksi. Artinya, ketika menerima pesan, penerima bereaksi dengan 
menyampaikan simbol atau lambang seperti berupa anggukan kepala atau dengan ujaran. Orang pertama bereaksi lagi setelah menerima respons atau umpan-balik dari orang kedua, dan begitu seterusnya.

Sebagai sebuah transaksi, komunikasi dianggap terjadi apabila seseorang menafsirkan perilaku baik verbal maupun non-verbal orang lain. Berdasarkan konsep ini, komunikasi pada dasarnya adalah suatu proses yang dinamis yang secara sinambung mengubah pihak-pihak yang berkomunikasi sehingga partisipan dalam komunikasi ini dianggap sebagai komunikator yang secara aktif mengirimkan dan menafsirkan pesan. Dengan kata lain, setiap pihak yang terlibat dalam komunikasi dianggap sebagai sumber sekaligus juga penerima pesan.

Kesiapan adalah kemauan dan kemampuan untuk melakukan sesuatu; juga mengacu pada lingkungan dimana individu atau lembaga telah dipersiapkan untuk tugas masa depan. Atas dasar ini, sukses kewirausahaan bergantung pada kemauan dan kemampuan kewirausahaan, dan pada kondisi lingkungan tertentu. Bila memiliki kapasitas kewirausahaan yang kuat, individu siap menghadapi atau menjalani perubahan. Psikolog dan sosiolog menggunakan empat konsep untuk mengukur kesiapan: sikap, nilai-nilai, pendapat, dan keyakinan. Konstruksi ini mempengaruhi tindakan atau perilaku seseorang (Houston et al. 2002). Penelitian sebelumnya juga membagi kesiapan menjadi dua domain, kognitif dan non-kognitif. Domain kognitif mengacu pada pengetahuan dan keterampilan bahwa seseorang membutuhkan, sedangkan non-kognitif domain menunjukkan, misalnya, karakteristik kewirausahaan atau sikap yang ada pada diri seseorang.

Hasil penelitian ini diharapkan dapat membantu menetapkan strategi komunikasi perubahan yang efektif dan bagaimana mengukur keefektivitasannya. Penelitian ini melibatkan peubah karakteristik pedagang, kredibilitas sumber pesan, pesan-pesan perubahan, komunikasi partisipatif, dukungan lingkungan, kualitas komunikasi, kapasitas kewirausahaan dan kesiapan dalam kaitannya dengan revitalisasi (kesiapan berubah). Dalam model ini komunikasi diharapkan dapat membangun kesiapan pedagang terkait dengan revitalisasi, dalam arti siap mengikuti program revitalisasi pasar. Kesiapan di sini didefinisikan sebagai suatu sikap yang secara kolektif yang tercermin pada sejauh mana pedagang pasar secara emosional dan kognitif cenderung menerima rencana perubahan, yakni revitalisasi.

Hasil penelitian menyiratkan bahwa sejumlah karakteristik pedagang mempengaruhi karakter hubungan komunikasi perubahan mereka. Temuan penelitian ini mengisyaratkan adanya karakteristik tertentu komunikasi perubahan yang perlu dipertimbangkan dalam mengaplikasikan komunikasi membangun kesiapan pedagang untuk menghadapi perubahan.

Kesiapan dibangun berdasarkan empat komponen, yakni pedagang merasa bahwa perubahan itu sesuai (kesesuaian), pedagang percaya bahwa pengelola pasar mendukung perubahan, pedagang melihat bahwa pengelola mampu membuat revitalisasi berhasil (self-efficacy), dan pedagang percaya bahwa revitalisasi menguntungkan mereka secara pribadi. Hasilnya menunjukkan bahwa indikator-indikator dari peubah tersebut pada umumnya masih rendah. Karenanya agar komunikasi menjadi efektif, diperlukan intervensi dari setiap 
proses tersebut, terutama elemen-elemen yang mempunyai efek baik langsung maupun tidak langsung terhadap elemen lainnya. Perlu disusun sebuah strategi komunikasi untuk membangun kesiapan pedagang berubah.

Berdasarkan temuan itu, tahap awal dalam komunikasi untuk membangun kesiapan pedagang berkaitan dengan revitalisasi adalah, menyiapkan juru bicara atau sumber pesan dalam komunikasi revitalisasi yang memiliki kredibilitas. Sumber informasi dan media yang digunakan untuk menyampaikannya mempengaruhi kesiapan pedagang. Sumber informasi dapat dikategorikan menjadi orang, media cetak dan sumber elektronik. Penggunaan sumber-sumber yang terbaik dapat membangun kesiapan karena sumber dapat membantu dalam menciptakan kesadaran tentang perlunya revitalisasi sebagai upaya tindakan komunikasi.

Selanjutnya, menyiapkan pesan-pesan perubahan yang mampu membangun dan menggugah serta memotivasi pedagang. Terkait dengan tugas ini, diperlukan komunikasi internal yang bertujuan meningkatkan kualitas sumber dalam membingkai pesan. Hal ini antara lain dapat dilakukan dengan meningkatkan frekuensi interaksi di antara pengelola pasar sehingga tercapai kesepahaman tentang revitalisasi di internal pengelola pasar.

Selama proses revitalisasi berlangsung, pengelola pasar harus terus memberikan motivasi dan dukungan dalam bentuk dukungan instrumental dan informasi kepada pedagang. Peningkatan dukungan informasi harus diberikan kepada pengelola pasar yang tidak terlibat dalam desain strategi sehingga ketika mereka berkomunikasi dengan pedagang dapat memberikan informasi yang relevan dan akurat. Kontak pengelola pasar, sesama pengelola pasar, pengelola dengan pedagang dan antar pedagang juga harus didorong untuk membantu pedagang mengatasi persoalan yang muncul selama pelaksanaan perubahan.

Komunikasi dua arah dengan fokus pada pesan tentang implikasi praktis atau risiko perubahan harus didorong. Untuk lebih mengembangkan ide-ide implementasi praktis dari perubahan, pedagang harus dilibatkan dalam komunikasi dua arah dengan pengelola pasar sehingga partisipasi pedagang makin meningkat. Pesan yang disampaikan pengelola pasar harus memperkuat perlunya perubahan dan memberikan gambaran tentang implikasi praktis yang dapat terjadi di tingkat individual pedagang, sehingga dapat membantu pedagang, termasuk mengurangi rasa ketidakpastian yang muncul selama proses transisi perubahan sehingga pedagang berpartisipasi.

Adapun bentuk-bentuk partisipasi menurut Sastropoetro (1988:12), di antaranya: partisipasi pikiran (psychological participation), partisipasi tenaga (physical participation), partisipasi pikiran dan tenaga (psychological and physical participation), partisipasi keahlian (participation with skill), partisipasi barang (material participation), dan partisipasi uang (money participation).

\section{SIMPULAN DAN SARAN}

Komunikasi untuk membangun kesiapan individu yang berkaitan dengan revitalisasi pasar telah melibatkan sumber pesan yang kredibel, komunikasi partisipatif, pesan yang mampu memberikan motivasi, mengingatkan hal-hal 
yang terkait dengan risiko, beragam media komunikasi yang diselaraskan dengan karakteristik pedagang sebagai partisipan.

Keterkaitan antar unsur komunikasi membangun kesiapan tersebut beragam, ada yang positif dan ada pula yang negatif. Komunikasi memberikan dampak yang negatif terhadap kesiapan perubahan bila sumber pesan tidak kredibel, pesan yang kurang mampu menggugah motivasi, kurang relevan dan tidak memberikan gambaran yang jelas kepada partisipan tentang risiko dari revitalisasi. Meski dalam beberapa hal, pengelola pasar yang berperan sebagai sumber pesan memiliki beberapa kelemahan, terdapat faktor positif, yakni keakraban dan daya tarik pengelola pasar dengan pedagang, pengelola pasar yang bisa bedampak positif dalam komunikasi membangun kesiapan.

Ini menunjukkan bahwa komunikasi membangun kesiapan pedagang terkait dengan revitalisasi pasar memiliki kekhasan yang terkait dengan kondisi psikologis partisipan. Dalam menghadapi perubahan, partisipan seringkali berada dalam kondisi ketidakpastian. Pada kondisi ini, kredibilitas sumber pesan, relevansi pesan, komunikasi partisipatif, serta komunikasi yang berkualitas menjadi sangat krusial. Komunikasi berkualitas menyangkut dimensi kejelasan, relevansi, akurasi dan kelengkapan informasi. Dalam komunikasi membangun kesiapan, memahami karakteristik pedagang sangat penting.

Secara keseluruhan unsur mulai dari karakteristik pedagang, sumber pesan, pesan, dan komunikasi partisipatif memberikan dampak positif terhadap kesiapan pedagang terkait dengan revitalisasi dengan kondisi kapasitas keriwausahaan pedagang tinggi. Dengan demikian, untuk membangun kesiapan pedagang, hal utama yang perlu dilakukan adalah membangun kapasitas kewirausahaan pedagang. Kurang maksimalnya pembangunan kapasitas kewirausahaan menghasilkan dampak negatif terhadap kesiapan pedagang.

Dalam membangun model atau strategi komunikasi dalam rangka persiapan menghadapi perubahan diperlukan pemikiran tentang ketidakpastian yang dihadapi oleh pedagang dan kapasitas kewirausahaan pedagang. Artinya, agar tujuannya tercapai, komunikasi harus bisa mengurangi ketidakpastian dan menumbuhkan keyakinan bahwa perubahan yang dilaluinya berhasil serta menghasilkan kondisi yang lebih baik dari kondisi saat dimulainya perubahan.

Dalam kaitan ini, selain pesan perubahan, peran saluran penyampai pesan sangat penting. Dalam kondisi ketidakpastian, pedagang menginginkan informasi selain relevan, juga cepat dan lengkap. Saluran yang hanya memungkinkan berlangsungnya komunikasi satu arah menjadi kurang efektif. Dalam kondisi seperti itu diperlukan saluran yang memungkinkan berlangsungnya komunikasi dua arah atau dialog. Namun demikian, dialog hanya efektif bila terdapat umpan balik. Untuk mendorong terjadinya umpan balik, dialog mensyaratkan adanya keterbukaan. Kebersamaan, rasa saling percaya, keadilan serta saluran komunikasi yang memungkinkan terjadinya dialog tersebut.

Ketidakpastian hendaknya dilihat sebagai tantangan dan peluang. Gagasan ini didasari pada pemikiran bahwa ketidakpastian bisa menghasilkan sesuatu yang positif, bisa juga negatif. Dengan menyusun sebuah strategi, pengelola 
program revitalisasi dapat menghindari atau mengatasi tantangan risiko dan memanfaatkan peluang yang ada selama proses revitalisasi. Perencanaan skenario adalah proses memposisikan beberapa informasi yang dipercaya dan diperkirakan bisa menjadi alernatif tindakan di masa depan sehingga keputusan diperkirakan dapat mengubah pemikiran saat ini, meningkatkan kualitas proses pengambilan keputusan, meningkatkan pembelajaran baik pedagang maupun pengelola pasar dan kinerja organisasi.

\section{DAFTAR PUSTAKA}

Arnstein SR.1969. A ladder of citizen participation. Journal of the American Institute of Social Planners, 4, 216-224

Berlo DK. 1961. The Process of Communication: An Introduction to Theory and Practice. New York: Holt, Rinehart, and Winston, Inc.

Bìchard M. 1999). Modernizing the policy process. London: PMPA

Carmines EG and Mclver JP. 1981. Analyzing Models with Unobservedd Variable in Bohrnstedt GW and Borgatta EF (editors). Social Measurement: Current Issues. Beverly Hills, CA: Sage

Crowley $A E$, and Hoyer WD. 1994. An integrative framework for understanding two-sided persuasion, journal of Consumer Research, 20, 561-574.

Holt DT, Armenakis AA, Field HS, and Harris SG. 2007. Readiness for organizational change. The Journal of Applied Behavioral Science, 43(2), 232.

Houston JM, McIntire SA, Kinnie J and Terry C. 2002. A factorial analysis of scales measuring competitiveness. Educational and Psychological Measurement, Vol. 62 No. 2, pp. 28498.

Innes J and Booher D. 2010. Planning with complexity: an introduction to collaborative rationality for public policy. Oxford: Routledge.

Liliweri A. 2011. Komunikasi Serba Ada Serba Makna. Jakarta: Kencana Prenada Media Group

Madsen SR, John CR, and Miller D. 2005. Work-family conflict and health: A studyof workplace, psychological, and behavioral correlates. Journal of Behavioral and Applied Management, 6(3), 225-247.

McQuail D \& Windahl S. 1989. Models of communication. In E. Barnouw, G. Gerbner, W. Schramm, T. L. Worth, \& L. Gross (eds.), International encyclopedia of communications, vol. 3 (pp. 36-44). New York: Oxford University Press.

Merrell P. 2012. Effective Change Management: The Simple Truth. Management Services, 56, 2, pp. 20-23

Miller KI and Monge PR. 1985. The influence of social information on employee anxiety about organizational change. Human Communication Research, 11, 365-386. 
Mubyarto. 1985. Peluang Kerja dan Berusaha di Pedesaan. BPEE., Yogyakarta.

Neuman LW. 2006. Social research methods qualitative and quantitative approachs. Boston: Pearson.

Pornpitakpan C. 2004. The persuasiveness of source credibility: A critical review of five decades' evidence. Journal of Applied Social Psychology, 34(2), 243281.

Rahayuningrum N, dan Widayanti T. 2008. Kajian Dampak Ekonomi Kerberadaan Hypermarket terhadap Ritel/Pasar Tradisional. Bulletin Ilmiah Litbang Perdagangan. Vol. II No. 1

Rahim SA. 2004. Participatory Development Communication as a Dialogical Process dalam White, SA. 2004. Participatory Communication Working for Change and Development. New Delhi: Sage Publication India Pvt Ltd.

Santosa A, dan Indroyono P. 2011. Pedagang Pasar Tradisional Terancam. Jurnal Ekonomi Rakyat, No. 108/13.

Sastropoetro SRA. 1988. Partisipasi, Komunikasi, Persuasi, dan Disiplin dalam Pembangunan Nasional. Bandung: Alumni.

Self DR, Schraeder M. 2009. Enhancing the success of organizational change: Matching readiness strategies with sources of resistance. Leadership \& Organization Development Journal, Vol. 30, No. 2, pp. 167-182.

Sumardjo. 1999. Transformasi Model Penyuluhan Pertanian Menuju Pengembangan Kemandirian Petani Kasus di Provinsi Jawa Barat. Disertasi. Program Pasca sarjana. Institut Pertanian Bogor. Bogor 